\title{
先天性内反足に対する内側解離術の治療成績
}

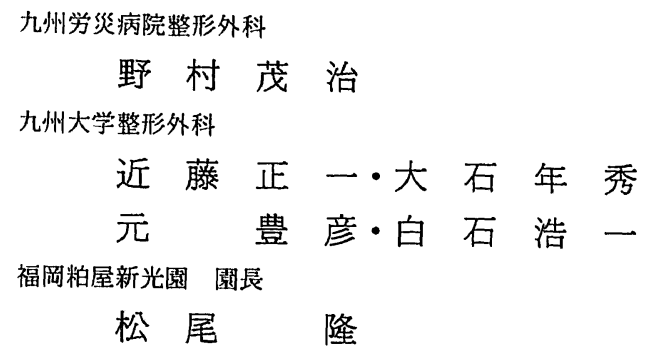

\section{Medial Release Operation of Club-foot}

by

Shigeharu Nomura

Department of Orthopaedic Surgery, Kyushu Rosai Hospital.

Masakazu Kondo, Toshihide Ohishi, Toyohiko Hajime and Koichi Shiraishi

Department of Orthopaedic Surgery, Faculty of Medicine, Kyushu University.

\section{Takashi Matsuo}

Shinkoen, the Handicapped Institution of Fukuoka Prefecture.

\begin{abstract}
The posterior release operation is one of the effective procedures for the equinus deformity of the idiopatic club-foot. But high incidence of recurrent adductus and varus deformities occurred after the posterior release alone. We have preferred the secondary midtarsal release operation in the infants between 2 and 4 years of age. This paper concerns the follow-up study of the secondary midtarsal release operation. Thirty-nine club-feet in 30 patients were used in this series. An average age at surgery was 3.5 years old and the length of follow-up was 6 years in average. Clinically, toeing-in gait was observed. Radiologic assessment of the adductus deformity was measured by the MTR angle. Clinically and radiologically, adductus deformity was corrected in 24 feet (60\%), but 12 feet $(30 \%)$ showed the recurrence and 9 feet required additional operations.
\end{abstract}

\section{はじめに}

先天性内反足の治療は後方解離術の導入によりアキ レス腱の延長のみでは得られなかった充分な尖足変形 の矯正を得ることが出来るようになり内反足治療に大 きな貢献をなしてきた。我々は後方解離術に際し尖足, 内反の再発を防止するため後脛骨筋腱および趾屈筋腱 延長の必要性を述べてきた。 この手術は生後 5,6 力 月に行っており術後は足外転外反位を保持する夜間副 子を用いている。術後暫くは矯正位はよく保たれてい
るが $2 ， 3$ 才頃になると内転内反の変形再発と共に toeing-in gait が目立ってくる.そこで toeing-in gait が見られ足外旋制限が出てきた症例に対し早期の内側 解離術を追加してきた。この内側解離術は尖足が cast 法により矯正された症例でも同様の症状が見られれば 行っている. 今回は後方解離術に内側解離術を追加し た症例の術後成績を検討したので報告する。

$$
\text { 対 象 }
$$

昭和 45 年より昭和 52 年迄に後方解離術を行い経過 観察が出来た症例は 43 例 57 足である。このうち後方 
解離術のみで経過を観察している症例は 9 例 12 足で 残りの 34 例 44 足は内側解離術をはじめ内後方解離 術，踵骨頸部外転骨切り術を行っている。

今回の対象とした後方解離術に内側解離術を追加し た症例は 30 例 39 足である. 後方解離術は生後 3 力月 より 24 力月, 平均 7 力月に行っており, 内側解離術は 1 才 3 力月上り 5 才迄, 平均 3 才 5 力月時に行ってい る. 調査時年岿は 5 才 6 力月より 14 才迄, 平均 9 才で ある.内側解離術後の Follow-up 期間は 2 年 2 力月よ り 9 年, 平均 6 年である. Follow-up 期間の短い症例 はその後更に追加手術を行ったためである.

\section{内側解離術手術法}

舟状骨結節を通る波状切開を用いる．母趾外転筋と 舟状骨内下方の趾屈筋腱腱鞘の間を鈍的に剥離して内 側足底神経を確認, 母趾外転筋とともに足底によける. 次いで後脛骨筋腱の腱鞘を縦切し腱を露出する。この 後脛骨筋腱を舟状骨付着部まで腱鞘と分離の後, 約 2 $\mathrm{cm}$ の長さでZ状に切離する。後脛骨筋腱の未梢が瘢 痕化し，滑動性がなく内果と舟状骨との間が厚い結合 織に覆われているものでは切離している。

舟状骨側に接して三角鞀带脛舟部, 後脛骨筋腱鞘, spring ligament を切離して距舟関節面を露出させ る.距舟関節包を外側まで可及的に切離する，次いで 内側足底神経を保護の上，長趾屈筋腱腱鞘を横切，更 に長母趾:届筋腱腱鞘を切離与る。これら届筋腱を下方 に引き下げると spring ligament および 2 分䩲帯が確
認されるのでこれを切離する。距骨下関節包は前方内 側のみ載距突起まで切離し，骨間鞁帯は温存する。舟 状骨を距骨頭外側に整復し K-wire で一時固定する。

術後は 5 週間ギプス固定の後，オルソレンにて作製 した夜間副子を 3 力月から 6 力月間使用する. K-wire は術後 2 ないし 3 週後の抜系時に抜去している，矯正 靴は使用していない.

\section{評 価 法}

臨床的には toeing-in gait の有無を観察した。レ線 的には内側解離の術前, 術後の前後レ線でMTR angle, 1st metataruso-talar angle, talo-calcaneal angle を, 調査時のレ線では navicular gradient angle を計測した，歩容も正常で機能的にも良好な足を優， 軽度の toeing-in gait がみられ経過観察が必要なもの を良，追加手術を行ったもの，および必要とするもの を不可とした（図 1).

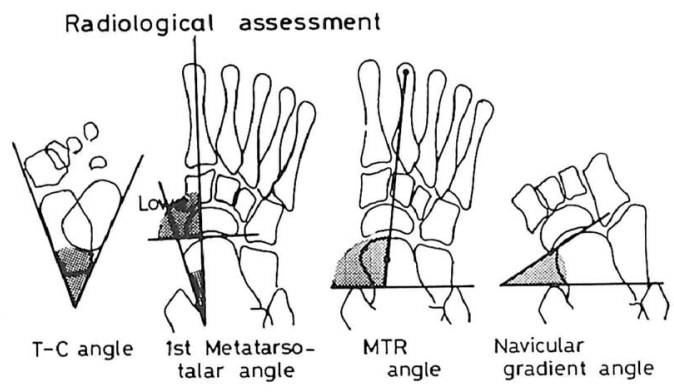

図 1 Radiological assessment
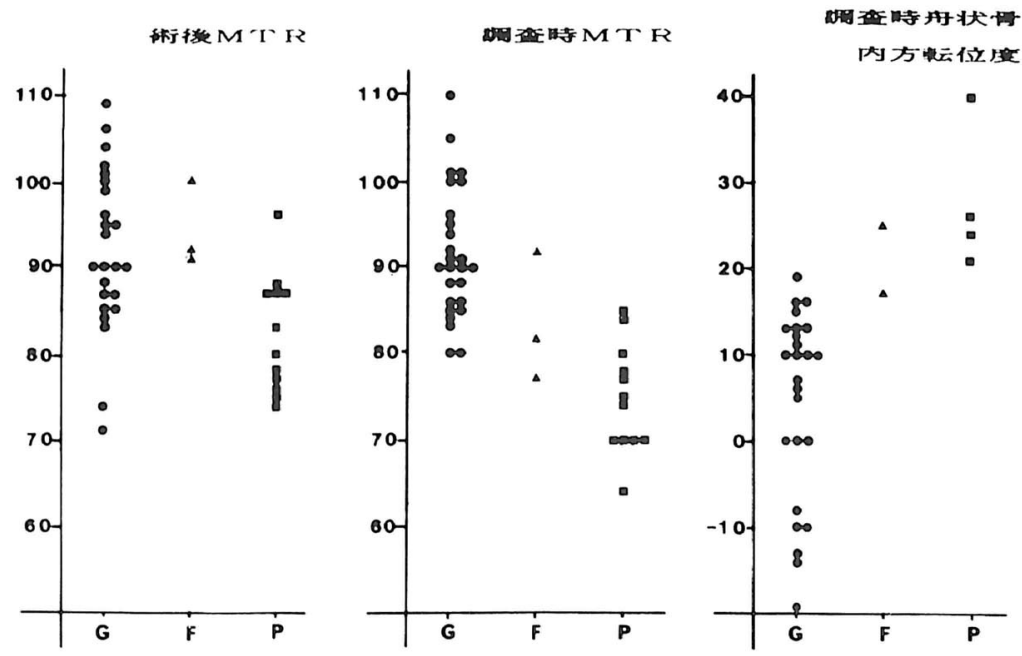

図 2 レ線計測と治療結果 ( $G$ ：優, F：良, P：不可) 
結果

6 例 9 足は内転変形再発のため踵骨頸部外転骨切り 術を行った。 3 例 3 足は追加手術が必要である。 3 例 3 足は軽度の変形はあるも経過観察している. 39 足中 24 足 $60 \%$ は充分に満足出来る結果であり, 12 足 $30 \%$ が不満足な結果であった。

レ線計測と治療結果との関係を成績優と不可の症例 で検討したところ両側例では変形が軽い方が良く矯正 されているものの全体的には術前の変形とは関係な く, 術後の MTR 角と調查時の MTR 角, 舟状骨内方 転位度においてのみ差異をみたが他の計測值において

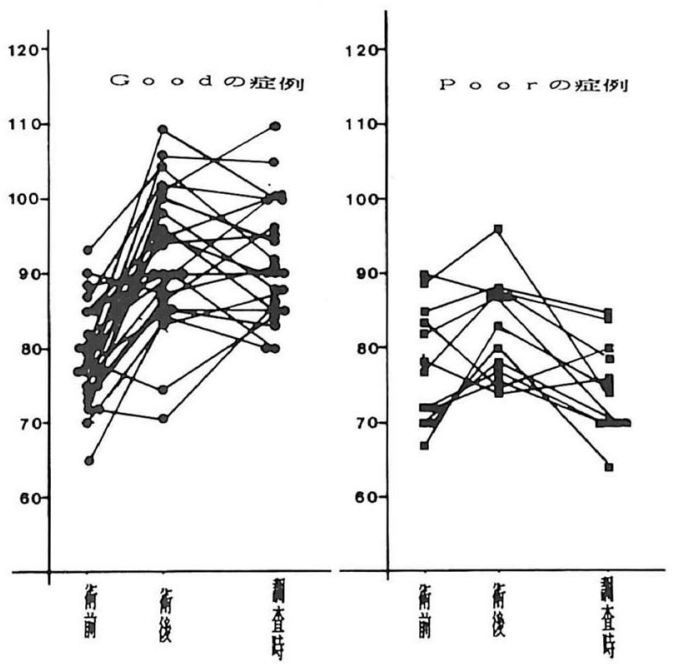

図 3 MTR 角の推移

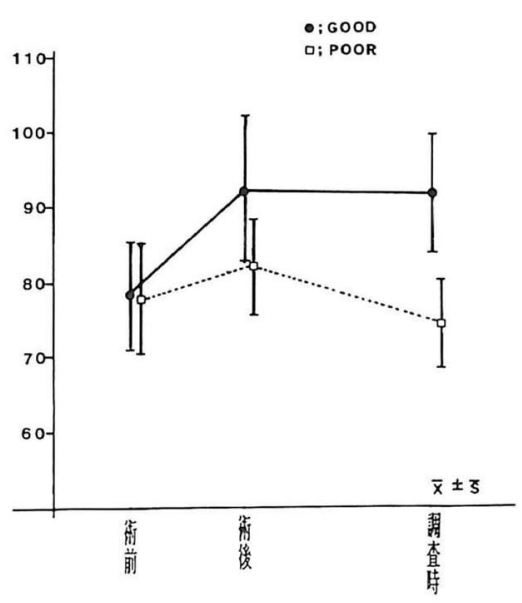

圆 4 MTR 角の推移
は差異を認めなかった（図 2 ）。

MTR 角の術前, 術後, 調查時の推移をみると不可の 症例では 1 例を除き術後明らかに稪正不足でありそれ がそのまま結果として反映している（図 $3 ， 4$ ）。

症

例

症例 1 H. R. 両先天性内反足

生後 6 力月目に両側の後方解離術を行う。術後は夜 間副子を装用していたが 3 才を過ぎて次第に内転内反 変形が現れ toeing-in gait がみられるようになった。 変形の改善傾向はなく 4 才時の術前レ線では MTR 角は右 80 度, 左 78 度と内転変形をみる. 術後 2 年充 分な矯正が得られている(図 5 ).

術後 8 年, 12 才時阽床的にもレ線的にも睬正位は良 く保たれている(図6).

症例 2 A.S. 右先天性内反足生後 6 力月目 に後方解離術を行う。術後は 2 才過ざ迄は夜間副子を 装用していたが以後放置していた． 3 才を過ぎて走行 時に toeing-in gait がみられるようになり，4才時に 内側解離術を行う。術前のMTR 角は 77 度, 術後 4 力 月では 106 度と良く䈛正されており11才 5 力月の調 查時でも 106 度と良く稪正位が保たれている（図 7 ).

4 year-old. 3 yrs. \& 7 months after P. R.

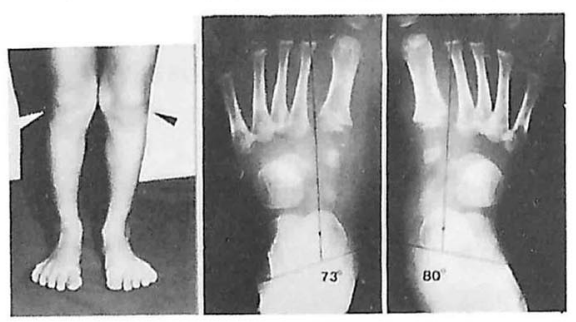

6 year-old. 2 years after midtarsal release

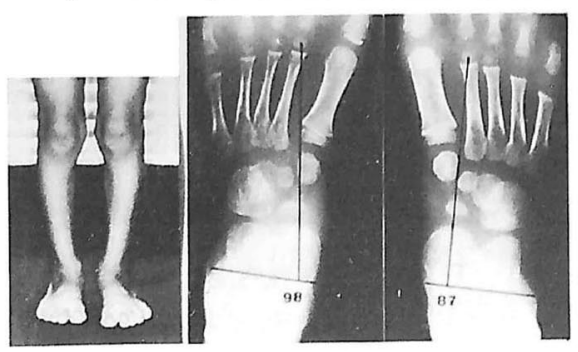

図 5 症例 1

上段, 後方解離術後 3 年 7 力月, 内転内反变形 がみられる。

下段, 内側解離術後 2 年. 


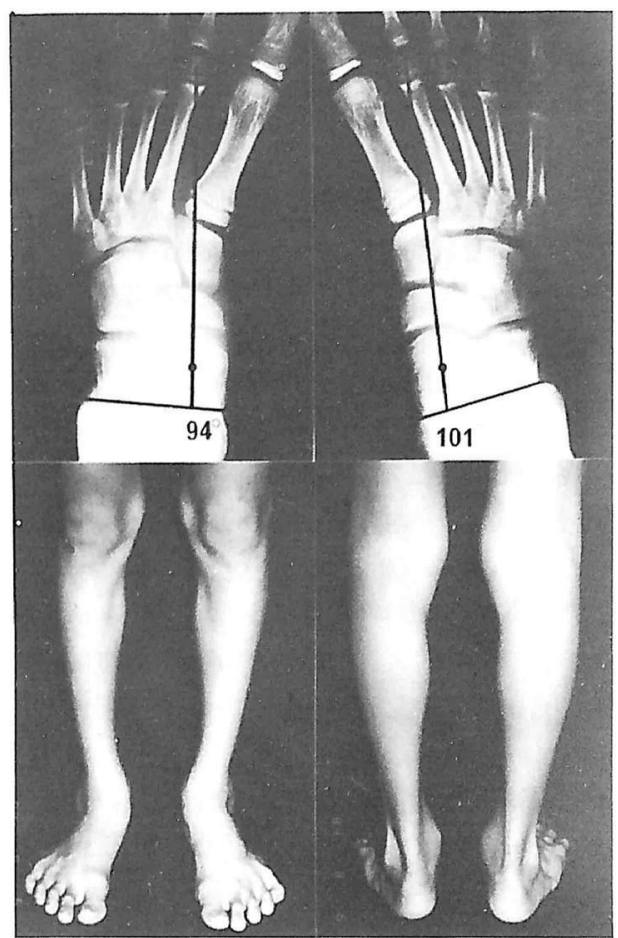

図 6 症例 1 .内側解嶕術後 8 年. 12 才時変形は良く 䂓正されている.

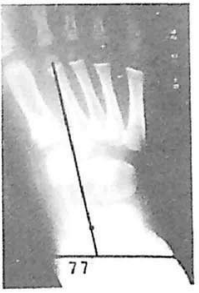

術前 4 才時

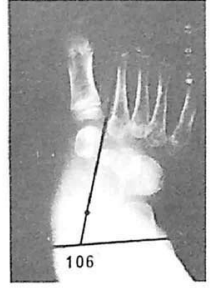

術後 5 力月

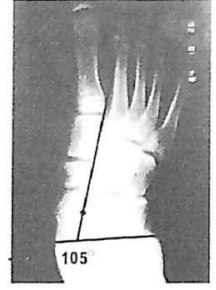

術後 7 年

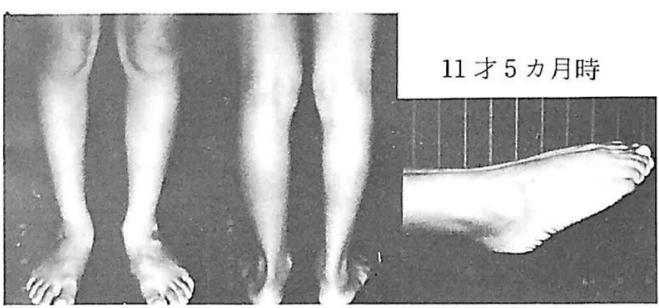

図 7 症例 2 . 生後 6 力月目後方解離術 4 才時内転変形あるため内側解離術を行なう。 11 才時変形は良く矯正されている.

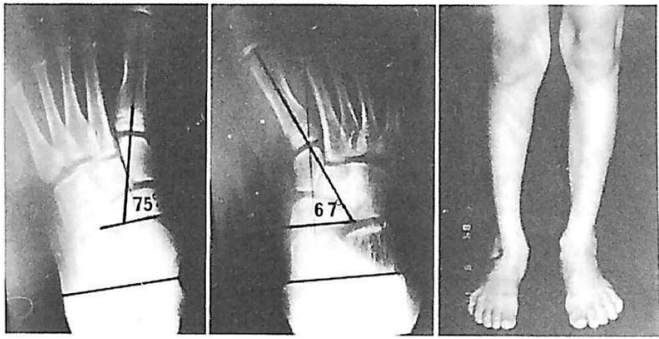

正常足

図 8 症例 3 . 舟状骨は距骨頭外側によく矯正されて いるが Lowe 角は $67^{\circ}$ と中足骨内反をみる.

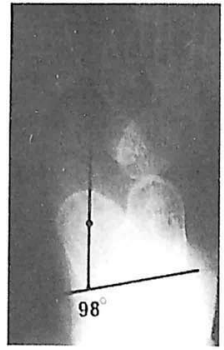

3 才 6 力月

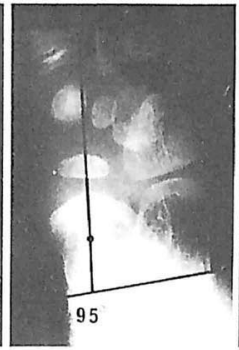

4 才 6 力月

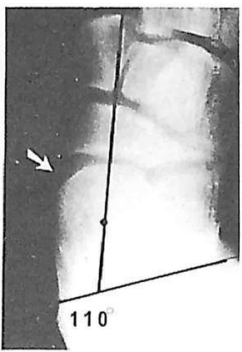

10 才 5 力月

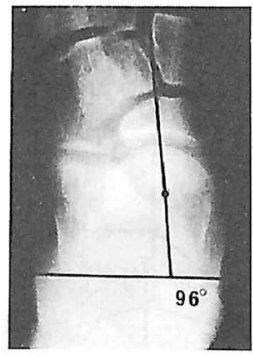

左後方解離術のみ

図 9 症例 4 , 内側解離術を追加した右足には距舟間に不適合がみられる.

症例 3 T. M. 右先天性内反足

1 才 10 力月に後方解離術, 4 才時に内側解離術を行

う. 9 才 2 力月時のレ線では舟状骨は距骨頭外側にあ り距踵舟関節は矯正位にある。しかしながら Lowe 角 は 67 度と中足骨内転がみられる（図 8 ).

症例 4 S. T. 両先天性内反足
生後 9 力月目に両足の後方解離術, 3 才時に toeing-in gait のみられる右足のみ内側解離術を行う. 術後矯正位が得られ経過も良好であり, 臨床的には問 題はない. しかしながら内側解離術を追加した右足の 方がより足外転が得られているもレ線では距骨頭の変 形と距舟関節に不適合がみられる (図 9). 


\section{考案}

先天性内反足に対し徹底した内転内反の cast によ る矯正と後方解離術にもかかわらずほとんどの症例に 前足部内転変形の発生をみることにより，後方解離術 に toeing-in gait がみられ，凹足変形，足外転制限の みられる症例に対し早期の内側解離術の必要性を述べ てきた ${ }^{5667)}$. 今回は後方解離術に内側解離術を追加し た two-stage operation で学童期に達した 30 例 39 足 の成績を調査した。 その結果は $60 \%, 24$ 足は充分に満 足出来, 早期に後療法を廃止するという我々の治療目 標を達し得た.しかしながら $30 \%, 12$ 足は追加手術を 行ったり，今後手術を必要とする．これ等不可の症例 を検討したところ矯正不足が原因となっている。この ことは技術的なものもあろうが, 我々の行っている内 側解離術では矯正位の獲得が得られない症例があるこ とを意味している，すなわち距骨下関節の骨間靱帯の 切離を含めた広範囲な解離, または外側解離, 踵立方 関節に対しての処置を考慮する必要があろう.

今回の調查で問題となったもう一つのことは Lowe 角の減少 $\left(\mathrm{Lowe}^{3)}\right.$ は外側角を計測しているが MTR 角 に合わせて内側角を計測した。）による中足骨内転， metatarusus addctus がある. Turco9 は軽度のもの は腓骨筋群の節力の低下によるもので次第に改善する が, 過度の矯正により生じた Skewfoot は治療が困難 であると述べている，我々の症例では舟状骨が充分に 外転位にあり後足部外反が得られている良好な経過を とっている 24 足中 5 足にレ線上見られたが, これ等の 症例では内反筋力の低下を intrinsic muscles で代償 している結果起こったのではないかと考えている. Turco9) のいうように過度の外反扁平足は戒めるべき であろうが軽度の外反扁平足に矯正出来た足は後療法 もいらず安心して経過をみており, 内反足治療の理想 像がこのへんにあるのではなかろうか.

後方解離術に再発が多いということで最近内後方解 離術が行われ244，かつ乳児に迄その適応を広げる傾向 にあるが118)その長期成績は待つとして, 我々の経験か らごく稀に castに抵抗する重度の奇形的内反足には 適応があろうが一般的には手術時期が遅くなる, 矯正 がどっちつかずになる, 足関節可動域とくに底屈制限 といった問題がある.

cast 治療の技術の向上, two-stage にわけるという 煩雑さはあろうが後方解離術のみでも経過良好例があ
ること，骨核が強くなり手術操作が容易である，底屈 制限が少ない, 後療法が楽であるといったメリットが あり内反足早期治療として一つの完成された方法と考 える.

結語

後方解離術後にみられる内転内反変形に対し早期の 内側解離術を追加して成縝を検討したが 39 足中 24 足 は良好な結果を得た。 3 足は軽度の変形が残存，9足 は追加手術を行い， 3 足は追加手術を予定している.

\section{参 考 文 献}

1）片平卓男ほか：内反足変形に対する一期後内例解離 術の経験：足の外科研労会誌， $2: 79-81 ， 1981$.

2) 北田 力ほか：先天性内反足の早期治燃一PR と PMRの適応についてー：足の外科研究会誌５： 77-82, 1984.

3) Lowe. L. M. et al.: Residual adduction of the forefoot in treated congenital clubfoot; J. Bone Joint Surg., 55-B : 809-813, 1973.

4) 藤井英夫：後内方解成術 (1); 整形外科 MOOK, $17: 160-170,1981$.

5）近藤正一ほか：先天性内反足に対する後方解離術の 限界と問題点；中部整㷋誌，20:444-447，1977.

6）野村茂治ほ力：後方解離術の問題点：中部整災誌， $19: 72-74,1976$.

7）松尾 隆活：先天性内反足に対寸万後方解減術の 限界と問題点：臨整外, $12: 213-224,1977$.

8）乗松敏晴ほか：早期手術法（Turco 法）による内反 足治療の検討：足の外科研究会誌，5:83-86，1984.

9) Turco, V. J.: Clubfoot, Churchill Livingstine, New York, 1981.

\section{質 問長崎大学 乗松 敏啨}

1. 後方解離術では再発が結構ありますが，他の方 法を考えますでしょうか.

2. 今回の調查にて, 後方解離術の明確な方針は分 りましたでしょうか?

\section{解 答学災病院 野村 茂治}

今回内側解離術を追加した症例の $30 \%$ に再発をみ たが、これをもって内後方解離術を早期に行なうとい う考えには反対である.1才末満の症例に画一的に Turco の内後方解離術を行なうことは足根骨に与え る影響が大きすぎる，又， castで治療し，尖足変形の みが不充分な生後 5,6 力月の症例をわざわざ 1 才過 迄待って手術をするというのは全く無だなことであ 
る.

内反足には種々の程度があり, 後方解離術だけでも 良い症例もあり, 内反変形がみられれば早期に内側解

離術を追加すれば良い. two-stage で困ることはせっ
かく歩けるようになったのだからという両親の情に流 され, 手術時期が遅くなり, 変形が増強して手術にな ることであろう。 